\title{
Community-Based Tourism: A Strategy for Sustainable Tourism Development of Patong Beach, Phuket Island, Thailand
}

\author{
Maythawin Polnyotee ${ }^{1} \&$ Suwattana Thadaniti ${ }^{1}$ \\ ${ }^{1}$ Interdisciplinary program in Environment, Development and Sustainability, Graduate School, Chulalongkorn \\ University, Thailand \\ ${ }^{2}$ Chulalongkorn University Social Research Institute, Chulalongkorn University, Bangkok, Thailand \\ Correspondence: Maythawin Polnyotee, Interdisciplinary program in Environment, Development and \\ Sustainability, Graduate School, Chulalongkorn University, Thailand. E-mail: maythawin.hos.msu@gmail.com
}

Received: June 25, 2015 Accepted: October 16, 2015 Online Published: November 20, 2015

doi:10.5539/ass.v11n $27 \mathrm{p} 90$

URL: http://dx.doi.org/10.5539/ass.v11n27p90

\begin{abstract}
This study proposes community-based tourism as a strategy for sustainable tourism development of Patong Beach. Direct observation, questionnaire and interview are research instruments. A result of analyzing 120 questionnaires of local people which displayed a negative impact including economic impact which was very high $(\bar{x}=4.53)$, social impact $(\bar{x}=4.28)$ and environmental impact $(\bar{x}=4.42)$ which were high so the total mean score was high $(\bar{x}=4.41)$. The Community-Based Tourism was adapted for solution all negative impacts which were mentioned earlier. The sreategies are namely 1. Political development strategy: (1.1) Enabling the participation of local people, (1.2) Giving the power of the community over the outside and (1.3) Ensuring rights in natural resource management. 2. Environmental development strategy: (2.1) Studying the carrying capacity of the area, (2.2) Managing waste disposal and (2.3) Raising awareness of the need for conservation.3. Social development strategy: (3.1) Raising the quality of life, (3.2) Promoting community pride, (3.3) Dividing roles fairly between women/men, elder/youth and (3.4) Building community management organizations. 4. Cultural development strategy: (4.1) Encouraging respect for different cultures, (4.2) Fostering cultural exchange and (4.3) Embedding development in local culture and 5. Economic development strategy: (5.1) Raising funds for community development, (5.2) Creating jobs in tourism and (5.3) Raising the income of local people.
\end{abstract}

Keywords: community-based tourism, sustainable tourism, strategic management, people's participation

\section{Introduction}

\subsection{Introduce the Problem}

Overdecades, turism has experienced continued growth and deepening diversification to become one of the fastest growing economics sectors in the world (UNWTO, 2015). The largest income earner for the country, the tourism industry is enormously significant for Thailand. Income from this sector increased continually from $14,880.58$ million US dollars in 2009 to the highest record of 39,282.32 million US dollars in 2013, with the average annual business expansion of about 7.58 percent. The highest gain came from European countries amounting to 48,373.57 million US dollars (37.22 percent of the total income), followed by East Asia, ASEAN, America, Oceania, South Asia, the Middle East and Africa, respectively (Department of Tourism, 2014).

Patong Beach is popular and famous among the Thai and foreigners as well as it is the one of the most beautiful beaches in the world certified by many international awards conferred to Phuket. It is attractive for relaxing, swimming, water recreations and water activities such as snorkeling, wind-surfing, scooter, boat-skiing, fishing and diving. In the past, tourism management and the local administration were limited by regulations and laws which did not relate to the area. Decentralization was granted to the local government by the central government, but the budget that the local government received is still not enough to solve the problems or develop itself. While Patong Beach has developed rapidly, the problems were generated continuously. This affected tourism of Patong beach in many dimensions.

\subsection{Explore Importance of the Problem}

Research of Jittima Kaewtae (Kaewtae, 2005) whose research topic is "Acceptance of News, Expectation and satisfaction of Thai Tourists toward Patong Beach, Phuket Province" found that the main reason in visiting 
Patong beach were the attractive environment of Patong beach. While, research of Panisa Meechinda (Panisa Meechinda, 2012) whose topic is "Thai and Foreign Tourists' Loyalty toward Tourism Destination in Chiang Mai and Phuket Province" found that in Phuket, the results indicated that domestic tourists are mostly female (62\%). Their motivation in traveling is to seek novelty and status. The most influential attributes of destination are scenery. In contrast, international tourists are mostly male $(60 \%)$ and $47 \%$ of them comes from Europe. Their motivation in traveling is to seek novelty and status. The most influential attributes of destination are scenery.

Moreover, research of Nanthana Rophandung (Rophandung, 2012) investigated in the topic "Factor of Influence toward Tourist's Decision of Traveling in Patong beach, Phuket province" found that the important factor which influences tourist's decision in traveling in Patong beach is tourism attractions especially, the beautiful of the beaches and valuable expenditures. The most favorite item of tourists in Patong is the cleanliness and the beautifulness of the beach. Mostly, tourists are satisfied to travel to Patong beach and will return to Patong beach in the future. In conclusion, the most important factors which influence the tourist's decision are especially beauty and cleanliness of the beach, satisfaction of traveling, valuable expenditures and many activities.

In addition, research of Maythawin Polnyotee and Suwattana Thadaniti (Maythawin \& Suwattana, 2014) whose research topic is "The Servey of factors Influencing Sustainable Tourism at Patong Beach, Phuket Island, Thailand" found that many factors affect sustainable tourism at Patong Beach are declining due to garbage accumulation in the area, waste water and landslide. In terms of the accessibility, traffic jams are occurring and the traffic signs are depreciating. At the same time, the tourism information accessibility is not up to date. Moreover, facilities such as parking, toilets, and rest areas are occupied by sellers and entrepreneurs, leaving tourists unimpressed. Finally, security, tourism leads to several crimes including drugs, prostitution, and problems of foreign workers and foreign entrepreneurs.

Issues surrounding the sustainable tourism development in Patong Beach are of three types. The first type is environmental problem: Originating from the service industry, the problems of garbage, emission, waste water, dust, lack of green zones and lack of rules at the beach front contribute significantly to the deterioration of the environment. Besides, there also exist risk of natural disasters such as tsunami and landslides. The second type of issue is socio-cultural problem; there are numerous socio-cultural problems, which include lack of tourists' safety, taking advantage of tourists, lack of local people's involvement, lack of education, poverty, poor public health, and problems of traffic, while the local community becomes increasingly commercialized. The third type of issue is economic problems. They include reliance on foreign workers, high competition for employment between local people and foreign workers, high budget expenses to solve problems, imbalance of tourism revenue and income distribution between local people and foreigner investors and insufficient budget to solve problems.

As mentioned above, there exist several problems which have affected development of Patong Beach as a world-class tourist destination. Thus, it is very important and timely to investigate this issue and devise strategies as a key success factor for its sustainable tourism development so that it grows as a popular destination among Thai as well as international tourists.

\subsection{Objective of Study}

This study propose community -based tourism as a strategy for sustainable tourism development of Patong Beach, Phuket Island, Thailand

\subsection{Relevant Literature}

\subsubsection{Community-Based Tourism}

Community- based tourism (CBT) is tourism which residents manage their resources in community as the tourism supply and provide it to tourist. The residents earn income as land managers, entrepreneurs, service and produce providers, and employees. At least part of the tourist income is set aside for projects which provide benefits to the community as a whole. For the host community to use tourism as a strategy for community development; it should apply a "holistic" view to analysis and understand the community situation. It will help host community maximize the capacity of CBT to act as an effective and sustainable community development strategy. The five principle aspects are (1) economic; income from local production, diversified local economy and self-reliance (2) social; people-centered development, social justice, satisfying quality of life and active community organizations (3) political; community participation, development in response to the community needs and democratization (4) cultural; formal and informal education, local culture passed on to the next generation and cultural preservation and (5) environmental; natural resource management rights, environmental responsibility and natural resource conservation (Mintzberg, 2009). In conclusion, community-based tourism 
enables the tourist to discover local habitats and wildlife, and celebrates and respects traditional cultures, rituals and wisdom. The community will be aware of the commercial and social value placed on their natural and cultural heritage through tourism, and this will foster community based conservation of these resources.

\subsubsection{Sustainable Tourism}

Sustainable tourism is a tourism which is an achieving growth in a manner that does not deplete the natural and built environment and preserve the cultural, history, heritage, and arts of the local community (Edgell, 2006). Moreover, it means achieving a particular combination of numbers and types of visitors, the cumulative effect of whose activities at a given destination, together with the actions of servicing businesses, can continue into the foreseeable future without damaging the quality of the environment on which the activities are based (Middleton, 1998). In addition, sustainable tourism is tourism which people can participate and gain benefit from such as income or even facilities in community which are developed from tourism activities. Not only will the resources and local people get benefit from sustainable tourism, but also the private sector. In terms of tourists, sustainable tourism is an instrument to make them realize about the importance of resources, when they are satisfied with tourism, at the same time they might not destroy tourism resources because they will keep in their mind that the resources belong to them. Nevertheless, sustainable tourism effort should be realized with effective, which should not be left behind to the next generations to solve it because they like the present generation will use the resources without solving the problems from the former generation as the concept of sustainable development.

\subsubsection{Strategic Management}

Strategic management is a continuous process that appraises the business and industries in which the organization is involved, appraises its competitors and fixes goals to meet the present and future competitor's and then reassesses each strategy. In term of process of sustainable tourism strategy, it consists of (1) an analysis of the status-quo (2) methods for collecting this information (3) strategic development and (4) action plan (Marbef.org, 2012). In conclusion, the strategic management is the process of management which the responsible person uses to manage tourism in the area for being sustainable tourism destination with 4 steps, which are environment scanning, strategy formulation, strategy implementation and strategy evaluation.

\subsubsection{People's Participation}

Participation is the result of an overall agreement between members of a group whose intention and direction for changing are enough to generating a new project. The National Village and Urban Community Fund Office, the Office of Institute of Rajabhat Council and the Office of the Higher Education Commission (2002) specified participation as that people or community can participate in decision on local development policy and participate in benefit distribution as well as participate in any projects evaluation control of their local. Furthermore, Wanruks Mingmaneenakin (1988) summarized that people participation is an active and full participation of stakeholders in every step of community development project, especially participation in power, decision and responsibility. Participation assures that stakeholders meet their demand and get benefit equally which were related with the Ladder of citizen participation concept of Sherry Arnstein who has been writing in 1969 about citizen involvement in planning processes in the United States, described a "ladder of citizen participation" that showed participation ranging from high to low. The ladder is a guide to seeing who has power when important decisions are being made. It has survived for so long because people continue to confront processes that refuse to consider anything beyond the bottom rungs (1969). In conclusion, participation means that people are closely involved in the economic, social and cultural and political processes that affect their lives. People may in some cases have a complete and direct control over these processes - in other cases the control may be partial or indirect. People have constant access to decision making and power. Participation in this sense is an essential element of human development. It generally refers to people's involvement in particular projects or programs. But today, participation means an overall development strategy focusing on the central role that people should play in all spheres of life. Human development involves widening their choice and greater participation enables people to gain for themselves, access to a much broader range of opportunities.

\section{Methodology}

\subsection{Data Collection}

2.1.1 The Survey

The survey was done at the initial stage of the data collection to get an overview of the contexts.

\subsubsection{Observations}

(1) Participatory observation such as visiting tourist attractions, joining the festival to be familiar with the tourist 
activities and places such as Songkran festival, Patong carnival, etc.

(2) Non-participatory observation was an activity which the researcher did not take part in, such as community's daily life and selling activities.

\subsubsection{Questionnaire}

The questionnaire was used to collect the data from the local people. The details covered all objectives and contents of the study.

\subsubsection{In-depth Interview}

In-depth interviews were carried out formally and informally to elicit perspectives and perceptions of stakeholders in detail, concerning the research objectives and contexts.

\subsection{Key Performance and Sample Sizes}

\subsubsection{Key Performance}

The key performances in this study consisted of stakeholders namely; 1 local agency (Patong city or Patong Municipality), 4 entrepreneurs (accommodation, travel agent, entertainment and souvenir-shop business).

\subsubsection{Sample Sizes}

Local people were selected by purposive sampling. There were 120 local peoples. The purposive sampling or judgment sampling was the method of selection which based on the discretion or decision of the researcher. It is related to the objectives of the research and it could reflect the representatives of sampling.

\subsection{Instruments}

\subsubsection{In-depth Interview}

It was conducted with the entrepreneurs and local agencies who were encouraged to express their opinions and role in tourism, the interviews consisted topics of existing tourism policy, tourism management and conservation, carrying capacity, participation and tourism impacts.

\subsubsection{The Questionnaire}

It was designed to explore the perspective and participation of local people in sustainable tourism development for Patong beach which consisted topic namely; tourism impacts, carrying capacity, local and national tourism policy and people participation in 4 dimensions (planning, management and operation, benefit distribution, evaluation and monitoring). To order that, the researcher used Likert scale to evaluate the respondents

\subsection{Data Analysis}

\subsubsection{An Analysis of Qualitative Data}

The data from interviews, observations and the literature review were organized and classified to discover the diversity of phenomena within the area. It was categorized in term of phenomena, similarities, and differences with support of reason manifest through informants. They were synthesized and displayed descriptively according to the conceptual framework. This analysis was concerned with concluding, defining, and analyzing between tourism and the area concerned. It also included the interpretations of the research finding according to the research objectives, theoretical framework, and concepts in order to explain and analyze the finding more effectively.

\subsubsection{An Analysis of Quantitative Data}

The data was analyzed to obtain statistical frequency, percentage, mean and standard deviation. It was coded on to the SPSS for Window program. The results from the SPSS for Window were presented in tables with descriptive explanations for the figures. Finally, it was analyzed for their relationships and interpretations according to the research objects and conceptual framework of the investigation.

\section{Results}

\subsection{The Background of Local People Respondents}

According to 120 questionnaires, it was found that $70.80 \%$ of local people are female and $29.20 \%$ of local people is male. The age of local people is mostly between $31-40$ years $(45.00 \%)$. The education of local people is mostly bachelor degree $(54.17 \%)$. The occupation of local people is mostly private staff $(60.00 \%)$. The monthly income of local people is mostly between 10,001-20,000 baht (52.50\%). Their background is illustrated in Table 1 below. 
Table 1. The background of local people respondents

\begin{tabular}{cccc}
\hline & Input data & Number & Percentage \\
\hline \multirow{2}{*}{ Sex } & Male & 35 & 29.20 \\
& Female & 85 & 70.80 \\
& $\leqq 20$ & 3 & 2.50 \\
Age (years) & $21-30$ & 49 & 40.80 \\
& $31-40$ & 54 & 45.00 \\
& $41-50$ & 14 & 11.70 \\
Education & $51-60$ & 0 & 0 \\
& $\geq 61$ & 0 & 0 \\
& Primary School & 9 & 7.50 \\
& Junior High School & 17 & 14.20 \\
& Senior High School & 26 & 21.70 \\
& University & 65 & 54.20 \\
& $\leqq 10,000$ & 17 & 14.20 \\
& $10,001-20,000$ & 63 & 52.50 \\
& $20,001-30,000$ & 26 & 21.70 \\
& $30,001-40,000$ & 11 & 9.20 \\
& $40,001-50,000$ & 3 & 2.50 \\
& $\geqq 50,001$ & 0 & 0 \\
\hline
\end{tabular}

\subsection{Factors Influencing Its Sustainable Tourism Development}

The factors influencing sustainable tourism at Patong beach were presented as a result of analyzing 120 questionnaire of local people respondents which displayed a negative impact including negative economic impact which was very high $(\bar{x}=4.53)$, negative social impact which was high $(x=4.28)$ and negative environmental impact which was high $(\bar{x}=4.42)$ so the total mean score was high $(x=4.41)$. They were related with the perspective of all interviewees with negative impacts such as garbage problem, waste water, air pollution, crime, and insecurity of life and belonging. Therefore, the local agency should recognize these problems and find out ways to solve these problems. If the local agency ignores these problems, the tourism at Patong beach could decline and risk unsustainable tourism. Moreover, the factor influencing sustainable tourism was moderate of local participation $(x=2.78)$. It was related with perspectives of all association by interviewing that they have low participation in all activities which affected to sustainable tourism development at Patong Beach. The impacts are illustrated in Table 2 below.

Table 2. The attitude of local people respondents on tourism impact

\begin{tabular}{cccc}
\hline Issue & $\bar{x}$ & SD & Level \\
\hline Positive Social Impact & 3.38 & 0.99 & Moderate \\
Positive Environmental Impact & 2.80 & 1.04 & Moderate \\
Positive Economic Impact & 3.84 & 0.91 & High \\
Negative Social Impact & 4.28 & 1.08 & High \\
Negative Environmental Impact & 4.42 & 0.88 & High \\
Negative Economic Impact & 4.53 & 0.83 & Highest \\
People Participation & 2.78 & 1.03 & Moderate \\
Total & 3.72 & 0.97 & High \\
\hline
\end{tabular}


In conclusion, tourism management at Patong Beach has not been efficient and that it affects the local people. Thus, the high level of negative impact is the factors that affect sustainable tourism at Patong Beach. Therefore, stakeholders should initiate action for sustainable development of tourism at Patong Beach.

\subsection{Strategy for Sustainable Tourism Development of Patong Beach}

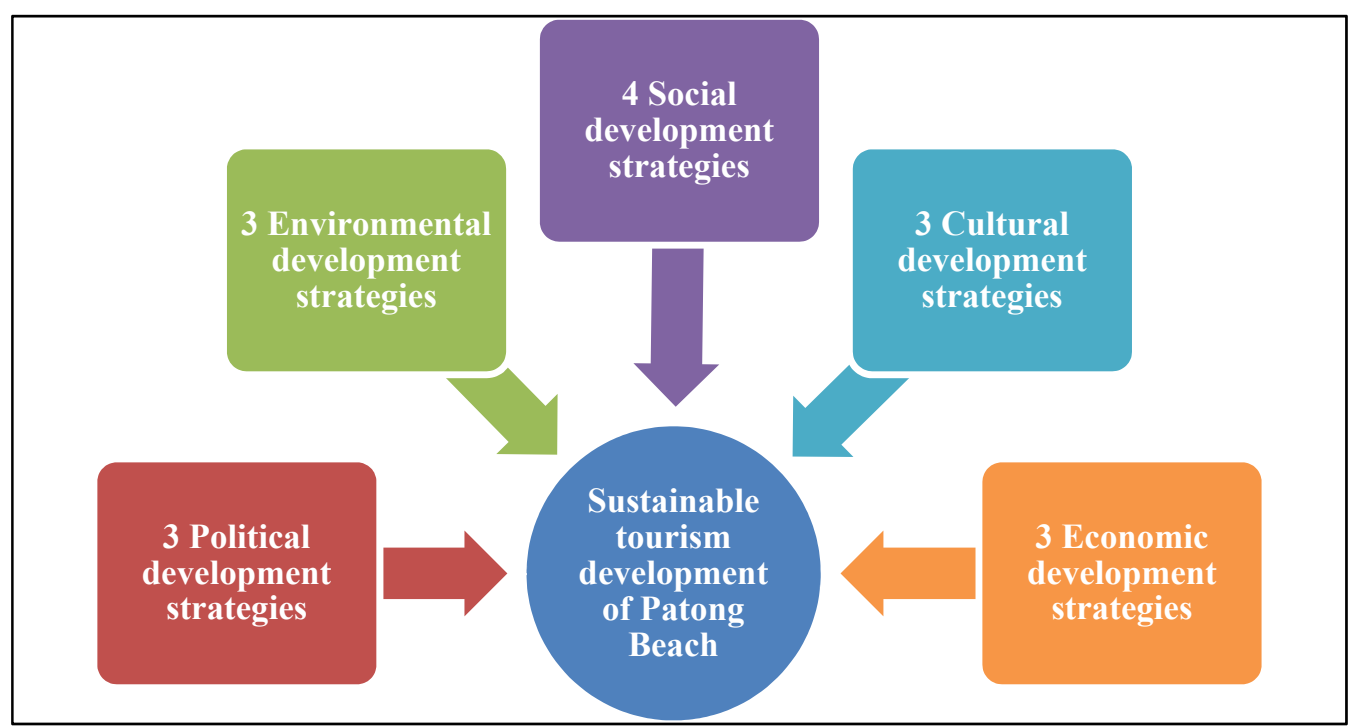

Figure 1. The Strategy for sustainable tourism development of Patong Beach Adapted from Community-Based Tourism Handbook (Mintzberg, 2009)

As shown on Figure 1, the strategy by adaptation of community-based tourism is launched to sustain and develop tourism in the community as one step to become a sustainable world-class tourist destination. This can be done by doing the following:

1. Political development strategy; local agency should (1.1) enable the participation of local people by strengthen local institutions to enhance local people's participation and promote local people as the representatives of whole residents actively involved in local government. Local agencies empowers (1.2) the power of the community over the outside by campaigning to promote the benefit of tourism development which is provision by providing communities with information and awareness before they make a decision to whether participate or not. Local agency (1.3) ensure rights in natural resource management by enhancing community strengthens itself and empowers local people to manage their resources.

2. Environmental development strategy: All stakeholders should (2.1) study the carrying capacity of the area which aims to determine the potential of tourists and residents' resources utilizing in the area. Moreover, (2.2) they should manage waste disposal together by reducing the amount of waste they produce being the best way to help the environment. Moreover, reusable items process can make waste possible to create new products out of the materials from the old ones to recycle. At the same time, all participants (2.3) raise awareness of the need for conservation by educating in support of campaigns to achieve specific conservation outcomes, educate to enhance visitor experiences, work with schools in smaller communities on interactive programs designed to enhance specific conservation outcomes.

3. Social development strategy: All participants (3.1) raise the quality of life; support events, activities and festivals concerning with a healthy, lifestyle, wellbeing, mindfulness and exercise in the public area, create the protection of any crime such as CCTV installation to cover all areas provide rescue staff efficiency, promote public safety campaign, encourage road and transport safety education in school, workplaces and community along with the transport regulation enforcement and provide public parks and green zones for community's activity. They should (3.2) promote community pride by expanding it through projects and community action to promote a cleaner, healthier, safer, more beautiful Patong beach in all aspects. They should (3.3) divide roles fairly between women/men, elder/youth by fostering horizontal linkages between different organizations and actors involved in human settlements development: politicians, activists, professionals, employers, tourists and 
beneficiaries, maintain vertical linkages between the various levels of political power, specify interests and concerns with women, elder and youth have particular approaches towards managing their environments. Moreover, they should (3.4) build community management organizations such as creating a strong sense of community amongst a specific group of individuals, working from proven templates to develop their community through the community development process (they are proactive, not reactive) and so on.

4. Cultural development strategy: they should (4.1) encourage respect for different cultures by learning to accept and respect other cultures which is an important step that opens mind to the world and everyone's unique differences such as develop an open mind by Studying religion, taking a look at history, trying some new cuisines and talking to people. They also should (4.2) foster cultural exchange by fostering community appreciation and participation in cultural exchange, develop and extend the opportunities for stakeholders to engage in initiatives that promote cultural diversity in the municipality, support cultural expression that is original and pertinent to the residents of the municipality, provide opportunities for cross-cultural collaboration that build a shared sense of community identity. They should (4.3) embed development in local culture by utilising local traditions and culture as the basis for marketing tourism industries, invest in culture-based development and formulate culture-based investment policy.

5. Economic development strategy: Local agencies and all participants should (5.1) raise funds for community development by making community brand awareness and communication available to people through fundraising activities such as events, sponsored events, collections, raffles, supporter database, local clubs and societies and school fundraising. Local agencies should (5.2) create jobs in tourism by developing tourism policies for creating local products and local jobs as follows: developing policies that harness benefits from tourism to empower communities as volunteers or staffs, protecting natural resources, promoting social cohesion and cultural identity, and ensuring that tourism policies are based on the broad participation of local communities and that they promote local employment and local ownership over the natural resources that make those areas valuable touristic destinations. Local communities and stakeholders should be included in tourism initiatives from planning to implementation to ensure fair and sustainable economic returns and also support the creation of tourism-oriented micro, small and medium-sized enterprises (M/SMEs), among others, by facilitating access to finance through credit and loans for local entrepreneurs, particularly for the poor and other disadvantaged groups. Specific support to tourism cooperatives should be provided which promote economic advantages through the pooling of resources, knowledge and skills, sharing of risks and benefits, while enhancing community ownership and autonomy, encourage and provide incentives for major tourist businesses to make basic infrastructure, including water and power utilities, available to the communities in which they are operating. Local transport services should be integrated such as personal taxis, rather than offering separate and expensive hotel-run shuttles and services. Utilizing and developing a local transport industry directly generates employment and income. Local employment should be supported through the development of job outreach programs that raise awareness among the local population about job prospects in tourism and assist local residents with finding and retaining jobs in tourism and related sectors. The environmental impact of major tourism developments should be evaluated and monitored and local labor used to protect and maintain the environment. Moreover, they should (5.3) raise the income of local people by stimulating the creation of new jobs and income opportunities in rural areas such as non-agricultural and other non-primary production activities, provide appropriate land-use frameworks in order to support the establishment of agricultural activities and both agricultural and non-agricultural services related to sustainable rural development.

\section{Discussion}

Patong Beach has plenty of tourist attractions. Tourists all over the world who come to Thailand do not miss traveling to Patong Beach. These tourist spots are not the only reasons why people travel here. Other factors such as accommodation, facility and security/safety also have an impact on the influx of tourists to the place. This research proposed development strategy for sustainable tourism of Patong Beach, Phuket Island, Thailand in 4 elements of tourism namely: tourist attractions, accessibility, facility and security/safety, which environment, social and economic problem solutions are included in each element. Finally, a strategy for development of sustainable tourism at Patong Beach will be useful to retain, sustain, preserve and conserve existing resources for the next generation the sustainable tourism development way.

Future research should focus on the impact of tourism in Patong beach in three dimensions, namely environmental, social and economic. Moreover, understanding its context and background before finding strategies is necessary in order to ensure their effectiveness. The present research found that there is a serious lack of people's participation and understanding of the principle of community-based tourism development and management. Therefore, future research should focus on how to encourage stakeholders' participation in tourism 
development and management in Patong beach, and also on how to ensure equitable distribution of the benefits among them. The suggestions of tourism development at Patong beach are as follows;

1. Promote and support local residents and entrepreneurs to participate in environment conservation, social preservation and economic development by giving them a chance to participate in designing local plans and policies with respect to sustainable tourism development.

2. Revise and update all the present laws, regulations and penalties. This is a contradiction.

Enforce the ministry regulations of the environmental protected area 2010 in terms of Allocation of protected area in Phuket province(ONEP, 2010) for managing Patong beach in sustainable tourism development. Moreover, the law submitted concerning tourism should require the Tourism Authority of Thailand (TAT) participation as being an advisor of tourism planning and law. Tourism academics can be encouraged to participate at this stage.

3. Community-based tourism (CBT) should be utilized as a tool of sustainable tourism development which focuses on all aspects including importance of politics which is being as the tool of participation in local administration. The other aspects concern the environment, which all stakeholders have to protect and conserve together, social aspect which is all stakeholders in this area have to protect them from any harm and develop it for their livelihood. In terms of cultural aspect which is include tangible and intangible items for preserving its unique local cultures for the next generation, and economic aspect, involving revenue to benefit stakeholders' participation.

4. Organized fund for local tourism. The fund can be set up from the government's annual budget distribution as well as donations from the community, entrepreneurs, local organizations and local agencies.

5. Campaign for environmental conservation in the area through all media i.e. television, radio, newspapers, magazines, website, leaflets and guidebooks in Thai and English as well as other languages. It would increase the awareness of all people including local people and tourist to conserve tourism resources together. Moreover, local agencies should encourage women, elder and youth to participate in local management equality.

The following are specific recommendations as areas of investigation for further research drawn from this study;

1. Drawing qualitative tourists as a new market for retaining its status as a world-class tourist destination in the long run.

2. Development of tourism marketing mix based on sustainable tourism development.

3. Encouragement for people's participation in tourism management by utilizing Community Based Tourism (CBT) concepts.

4. Promotion of local culture through diversification of tourism attractions.

5. Prevention of natural disasters, to earn tourists' trust in tourism at Patong beach

6. Development of safety zone and protect lives and belongings of tourists and also residents.

7. Development of world-class tourism based on professionalism.

8. Popularization of tourist attractions and events to promote world-class tourism.

9. Conservation of tangible and intangible attractions through minimizing negative impacts of tourism.

In addition, further research should be done through quantitative and qualitative research to increase effective results. Moreover, tourism research should be integrated with other sciences because it is at present a disciplinary knowledge.

\section{Acknowledgements}

We are grateful to "THE 90th ANNIVERSARY OF CHULALONGKORN UNIVERSITY FUND (Ratchadaphiseksomphot Endowment Fund)", Graduate School, Chulalongkorn University who supported fund for achievement of this research.

\section{References}

Department of Tourism. (2014). Statistic of Tourist revenue of year 2013. Bangkok. Retrieved from http://www.tourism.go.th/home/details/11/221/621

Edgell, D. L. (2006). Managing Sustainable Tourism: A Legacy for the Future. New York: Haworth Press.

Mintzberg, H. (2009). Rebuilding Companies as Communities. Harvard Business Review (July-August 2009).

Kaewtae, J. (2005). Acceptance of News, Expectation and Satisfaction of Thai Tourists toward Patong Beach, 
Phuket Province (Master of Arts). Dhurakij Pundit University, Bangkok. (Abstract).

Marbef.org. (2012). Impact of tourism in coastal areas: Need of Sustainable tourism strategy. Retrieved from http://www.marbef.org/wiki/Impact_of_tourism_in_coastal_areas:_Need_of_sustainable_tourism_strategy\# Sustainable_Tourism_Strategy

Maythawin, P., \& Suwattana, T. (2014). The Survey of Factors Influencing Sustainable Tourism at Patong Beach, Phuket Island, Thailand. Mediterranean Journal of Social Sciences, 5(9), 650-655. http://dx.doi.org/10.5901/mjss.2014.v5n9p650

Middleton, V. T. C., \& Hawkins, R. (1998). Sustainable Tourism: A Marketing perspective. Massachusetts: Butterworth-Heinemann.

Mingmaneenakin, W. (1988). Thai local development. Bangkok: Thammasat University publishing.

Rophandung, N. (2012). Factor of Influence toward Tourist's Decision of traveling in Patong beach, Phuket province. Retrieved from http://www.thaithesis.org/detail.php?id=1122548000076

Office of the Higher Education Comission, M. o. E. (2002). Local research Self learning. Bangkok: S.R.Printing.

ONEP. (2010). Annoncement of Ministry regulation of the environmental protected area 2010: Allocation of proteced area in Phuket province. Bangkok: Office of Natural Resources and Environmental Policy and Planning.Retrieved from http://www.onep.go.th/images/stories/file/law24.pdf

Meechinda, P. (2012). Thai and Foreign Tourists' Loyalty toward Tourism Destination in Chiang Mai and Phuket Province. Retrieved from http://research.trf.or.th/node/2283

Arnstein, S. R. (1969). A Ladder of Citizen Participation. Journal of the American Planning Association. Retrieved from http://www.vcn.bc.ca/citizens-handbook/arnsteinsladder.html

UNWTO. (2015). Why tourism?: Tourism - an economic and social phenomenon. Retrieved from http://www2.unwto.org/content/why-tourism

\section{Copyrights}

Copyright for this article is retained by the author (s), with first publication rights granted to the journal.

This is an open-access article distributed under the terms and conditions of the Creative Commons Attribution license (http://creativecommons.org/licenses/by/3.0/). 